\title{
PENGARUH INTERACTIVE DEMONSTRATION TERHADAP PERUBAHAN KONSEP SISWA TENTANG TEKANAN ZAT CAIR PADA KELAS VIII SMP NEGERI 14 PALU
}

\author{
Fitriani K, Jusman Mansyur dan Muhammad Ali \\ Fitriani key@yahoo.com \\ Program Studi Pendidikan Fisika FKIP Universitas Tadulako \\ Jl. Soekarno Hatta Km. 9 Kampus Bumi Tadulako Tondo Palu - Sulawesi Tengah
}

\begin{abstract}
Penelitian ini bertujuan mengetahui pengaruh interactive demonstration terhadap perubahan konsep siswa tentang tekanan zat cair pada Kelas VIII SMP Negeri 14 Palu. Desain penelitian "The Non Equivalen Pretest-Posttest Design". Populasi penelitian adalah seluruh siswa kelas VIII SMP Negeri 14 Palu yang terdaftar tahun ajaran 2014/2015. Teknik pengambilan sampel adalah purposive sampling, sampel penelitian adalah kelas VIII B1 ( $n=18$ sebagai kelas eksperimen) dan Kelas VIII $A 1$ ( $n=18$ sebagai kelas kontrol). Instrumen penelitian adalah tes pemahaman konsep dan lembar observasi. Pengujian hipotesis dilakukan dengan menggunakan statistik nonparametrik dengan uji Mann-Whitney pada taraf signifikansi 0,05. Hasil penelitian menunjukkan bahwa terdapat pengaruh interactive demonstration terhadap perubahan konsep siswa tentang tekanan zat cair.
\end{abstract}

Kata Kunci: interactive demonstration, perubahan konsep.

\section{PENDAhUlUan}

Teori kontruktivisme menyatakan bahwa pengetahuan dibentuk (dikonstruksi) oleh siswa sendiri dengan lingkungan, tantangan dan bahan yang dipelajari ${ }^{[1]}$. Sebelum pembelajaran formal, siswa sudah membawa konsep awal yang disebut prakonsepsi. Prakonsepsi ini dapat sesuai dengan konsep ilmiah dan dapat juga tidak sesuai dengan konsep ilmiah. Konsep yang tidak sesuai dengan konsep ilmiah disebut miskonsepsi ${ }^{[2]}$.

Salah satu penyebab universal rendahnya pemahaman konsep fisika yang dicapai siswa adalah terjadinya kesalahan konsep (miskonsepsi) pada siswa [3]. Penelitian berkaitan tentang miskonsepsi fisika sudah cukup banyak dilakukan di Indonesia, namun belum bisa mengatasi miskonsepsi siswa [2]. Penanganan miskonsepsi selalu berkaitan dengan perubahan konsep. Perubahan konsep dalam pembelajaran fisika yang dimaksud adalah proses perluasan konsep (asimilasi) dan proses pembetulan konsep (akomodasi) ${ }^{[4]}$.

Perubahan konsep dapat terjadi jika anak tersebut merasa tidak puas dengan gagasan yang ada. Walaupun demikian, ketidakpuasan saja tidak cukup untuk mengganti gagasan lama dengan gagasan baru. Harus ditambahkan tiga kondisi, yaitu gagasan baru itu harus intelligible (dapat dimengerti), plausible (masuk akal), fruitful (memberi suatu kegunaan) ${ }^{[4]}$.
Penyampaian materi fisika seharusnya melibatkan siswa secara aktif sehingga siswa dapat menemukan hal-hal baru dari hasil pengamatan dan percobaan yang dilakukan serta mampu membuat struktur kognitif siswa menjadi goyah untuk dapat menerima konsep bermakna. Diperlukan suatu metode pembelajaran yang tepat agar berlangsung perubahan konsep pada siswa di dalam kelas.

Kemampuan siswa untuk mengkontruksi pengetahuan dapat terwujud jika siswa diberi kesempatan untuk mencari, menemukan dan menyimpulkan sendiri sesuai dengan pembelajaran inkuiri. Interactive demonstration merupakan pembelajaran berbasis inkuiri. Dalam pembelajaran ini dapat memberi kesempatan kepada siswa untuk mengamati secara cermat, memberi gambaran secara langsung dan dapat menumbuhkan sikap ilmiah sehingga efektif membuat siswa mengubah konsep yang salah menuju konsep ilmiah yaitu perubahan konsep.

Berdasarkan Penelitian sebelumnya menyimpulkan bahwa pembelajaran inquiryinteractive demonstration mampu memecahkan masalah fisika $1^{5]}$ dan metode demonstrasi terbukti lebih efektif dalam meningkatkan pemahaman konsep siswa ${ }^{[6]}$.

Berikut pemetaan interactive demonstration yang diduga dapat menghasilkan perubahan konsep sebagaimana disajikan pada gambar 1 


\begin{tabular}{|c|c|}
\hline $\begin{array}{c}\text { Interactive } \\
\text { demonstration }^{[7]}\end{array}$ & $\begin{array}{c}\text { Perubahan } \\
\text { Konsep }^{[4]}\end{array}$ \\
\hline 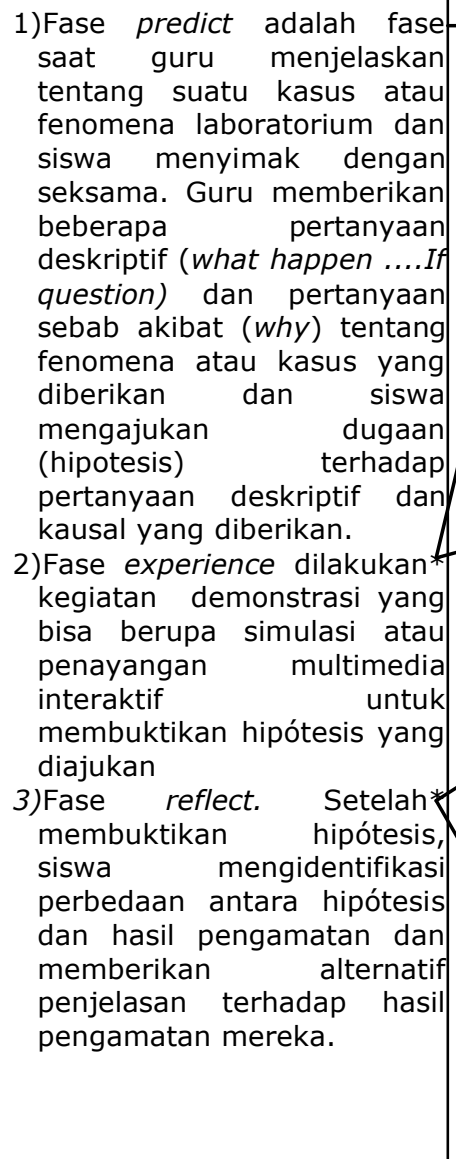 & $\begin{array}{l}\text { 1)Ketidakpuasan } \\
\text { anak akan } \\
\text { gagasan yang } \\
\text { dimilikinya } \\
\text { 2)Akomodasi } \\
\text { mendapatkan } \\
\text { konsep baru } \\
\text { yang dapat } \\
\text { dimengerti/intelli } \\
\text { gible), rasional } \\
\text { dan dapat } \\
\text { memecahkan } \\
\text { permasalahan } \\
\text { atau fenomena } \\
\text { baru } \\
\text { 3)Proses } \\
\text { akomodasi } \\
\text { (mendapatkan } \\
\text { konsep baru } \\
\text { yang masuk } \\
\text { akal/ plausible) } \\
\text { 4)Proses } \\
\text { akomodasi } \\
\text { (mendapatkan } \\
\text { konsep baru } \\
\text { yang memberi } \\
\text { suatukegunaan } / f \\
\text { ruitfull) } \\
\text { 5)siswa } \\
\text { memperluas } \\
\text { konsep atau } \\
\text { meluruskan } \\
\text { konsep yang } \\
\text { tidak tepat }\end{array}$ \\
\hline
\end{tabular}

Gambar 1. Bagan Hubungan Potensial Fase Interactive Demonstration dan Aspek Perubahan Konsep

Berdasarkan uraian di atas, dapat dinyatakan bahwa interactive demonstration adalah salah suatu pembelajaran yang potensial dapat menghasilkan perubahan konsep karena dirancang dengan melibatkan siswa secara aktif dalam proses berpikir. Peneliti tertarik melakukan penelitian untuk melihat pengaruh interactive demonstration terhadap perubahan konsep siswa tentang tekanan zat cair pada kelas VIII SMP Negri 14 Palu. Penelitian ini dapat dipandang baru karena dari peneliitian tersebut belum terdapat peneliti yang mengkaji secara khusus penerapan interactive demonstration dikaitkan dengan perubahan konsep.

\section{METODE PENELITIAN}

Jenis penelitian ini yaitu penelitian yang bersifat kuantitatif dengan rancangan eksperimen kuasi (quasi-experimental design)
Adapun desain penelitian yang digunakan yaitu the non ekivalen pretest-posttest design. Desain penelitian yang digunakan dapat dilukiskan seperti pada Tabel 1.

Tabel 1 The non ekivalen pretest-posttest design

\begin{tabular}{|c|c|c|c|}
\hline Kelompok & Pretest & Perlakuan & posttest \\
\hline Eksperimen & $\mathrm{O}$ & $\mathrm{X}$ & $\mathrm{O}$ \\
\hline Kontrol & $\mathrm{O}$ & - & $\mathrm{O}$ \\
\hline
\end{tabular}

Keterangan:

O : Pretest/Posstest

$\mathrm{X}$ : Pelakuan dengan menggunakan interactive demonstration

- $\quad$ : pembelajaran konvensional

Penelitian dilakukan di SMP Negeri 14 Palu. Populasi penelitian ini adalah seluruh siswa Kelas VIII SMP Negeri 14 Palu Tahun Pelajaran 2014/2015 terdiri dari 11 kelas. Sampel dalam penelitian ini berjumlah 36 siswa, Kelas VIII B1 ( $n=18$ sebagai kelas eksperimen) dan Kelas VIII A1 ( $n=18$ sebagai kelas kontrol). Teknik pengumpulan sampel yang digunakan adalah purposive sampling.

\section{HASIL DAN PEMBAHASAN}

\section{Hasil Penelitian}

\section{A. Hasil Tes perubahan Konsep Tentang Tekanan Zat Cair}

Peningkatan perubahan konsep siswa tentang tekanan zat cair yang diperoleh dari kelas eksperimen dan kelas kontrol yang dihitung menggunakan persamaan $\mathrm{N}$-gain disajikan pada Tabel 2.

Tabel 2 Hasil Skor Pretest, Posttest dan N-gain Kelas Eksperimen dan Kelas Kontrol

\begin{tabular}{|l|c|l|l|l|}
\hline Uraian & $\begin{array}{c}\text { Pretest } \\
(\%)\end{array}$ & $\begin{array}{c}\text { Posttest } \\
(\%)\end{array}$ & $\begin{array}{l}\text { N-Gain } \\
(\%)\end{array}$ & kategori \\
\hline Eksperimen & 18,06 & 78,47 & 73,82 & Tinggi \\
\hline Kontrol & 19,17 & 57,36 & 46,84 & Sedang \\
\hline
\end{tabular}

Berdasarkan data Tabel 2, dapat dilihat bahwa peningkatan perubahan konsep siswa untuk kelas eksperimen berada pada ketegori tinggi sedangkan untuk kelas kontrol berada pada ketegori sedang.Grafik perbandingan skor rata-rata pretest, posttest dan $\mathrm{N}$-gain antara kelas eksperimen dan kelas kontrol dapat dilihat pada gambar 2 .

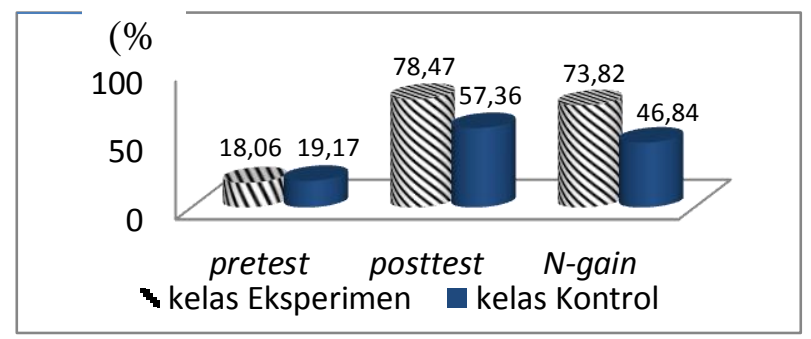


Gambar 2 Grafik Perbandingan Skor Rata-rata Pretest, Posttest dan $N$-gain Tes Perubahan Konsep antara Kelas Eksperimen dan Kelas Kontrol

\section{B. Uji Hipotesis}

Uji hipotesis ini digunakan untuk memastikan apakah hipotesis yang diajukan dapat diterima atau ditolak. Dalam penelitian ini menggunakan uji statistik nonparametrik dengan uji Mann-Whitney.

Tabel 3 Uji Hipotesis Kelas Eksperimen dan Kelas Kontrol

\begin{tabular}{|c|c|c|c|c|}
\hline Kelas & $\begin{array}{l}\text { Nilai } \\
\text { ratarata } \\
N \text {-gain } \\
(\%)\end{array}$ & $U_{\text {hitung }}$ & $\begin{array}{l}U_{\text {tabel }} \\
(\alpha=0,05)\end{array}$ & Keputusan \\
\hline Eksperimen & 73,82 & \multirow{2}{*}{10,5} & \multirow{2}{*}{109} & \multirow{2}{*}{$\begin{array}{c}\mathrm{H}_{0} \\
\text { ditolak }\end{array}$} \\
\hline Kontrol & 46,82 & & & \\
\hline
\end{tabular}

Berdasarkan Tabel 3 Nilai $U_{\text {hitung }}<\mathrm{U}_{\text {tabel }}$ atau $10,5<109$. Hal ini menunjukkan bahwa $U_{\text {hitung }}$ berada diluar daerah penerimaan Ho. Dengan demikian dapat dikatakan bahwa rata-rata skor perubahan konsep antara siswa yang mendapatkan pembelajaran interactive demonstration lebih tinggi daripada siswa yang mendapatkan pembelajaran konvensional. Artinya, terdapat pengaruh pembelajaran interactive demonstration terhadap perubahan konsep siswa tentang tekanan zat cair.

\section{Hasil Observasi}

Data aktivitas guru dan siswa diperoleh melalui observasi yang dilakukan oleh seorang observer setiap pertemuan menggunakan lembar observasi. Hasil observasi aktivitas guru dan siswa dapat dilihat pada Tabel 4.

Tabel 4 Hasil Observasi Aktivitas Guru dan Siswa Kelas Eksperimen

\begin{tabular}{|c|c|c|}
\hline Pertemuan & $\begin{array}{c}\text { Rerata Skor } \\
\text { Siswa (\%) }\end{array}$ & $\begin{array}{c}\text { Rerata Skor } \\
\text { Guru (\%) }\end{array}$ \\
\hline Pertemuan 1 & 80,55 & 87,93 \\
\hline Pertemuan 2 & 87,96 & 89,65 \\
\hline Pertemuan 3 & 90,78 & 93,10 \\
\hline $\begin{array}{c}\text { Rerata Total } \\
\text { skor (\%) }\end{array}$ & 86,43 & 90,22 \\
\hline
\end{tabular}

\section{Jawaban Hasil Tes}

Berikut ditampilkan beberapa kutipan jawaban siswa pada kelas eksperimen dengan menggunakan pembelajaran interactive demonstration tentang konsep tekanan zat cair untuk melihat perubahan konsep pada siswa melalui tes pemahaman konsep.

1) Soal tentang Tekanan Hidrostatika
Diberikan sebuah kasus pada bejana yang telah dilubangi dengan ketinggian yang berbeda-beda di atas lantai, pada lubang A terletak $5 \mathrm{~cm}$ dari dasar wadah, lubang B terletak $10 \mathrm{~cm}$ dari dasar wadah dan lubang $C$ terletak $15 \mathrm{~cm}$ dari dasar wadah. Lubang manakah yang memancarkan air paling jauh jarak jatuhnya dari bejana ke lantai? Jelaskan!" Hasil perubahan konsep K-05 mengenai konsep tekanan hidrostatis dapat dilihat pada Tabel 5.

Tabel 5 Perbandingan jawaban pretest dan posttest K-10

\begin{tabular}{|c|c|}
\hline No & \multirow[t]{2}{*}{ Jawaban siswa } \\
\hline 1 & \\
\hline \multirow[t]{11}{*}{ Pretest } & \\
\hline & ) lubang $A=5 \mathrm{~cm}$ dari dasar wadah \\
\hline & $B=10 \mathrm{~cm}$ dari dasar Wadah \\
\hline & $c=15 \mathrm{~cm}$ dari dasar wadah \\
\hline & lubang $B$ : Karena lubang b mengalami \\
\hline & beberapa dari dasar watah tabap \\
\hline & yg diberkan dari lubang a yg \\
\hline & dasar wadahnya sebasar $5 \mathrm{~cm}$. \\
\hline & ketika lubang b mendapat aliran \\
\hline & dari lubang a maka lubaing $b$ \\
\hline & maman earlean air paling jauh. \\
\hline Posttest & 1) Jiwabanya A karena lubang A tertetak \\
\hline & Paling baivah sehingaa, lubang A Menghasilicar \\
\hline & tekanan yg lebish besar dari pada lobang $B$ dan \\
\hline & 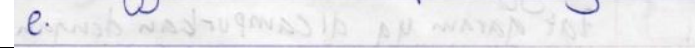 \\
\hline
\end{tabular}

Berdasarkan Tabel 5, dapat dilihat bahwa pada saat pretest $\mathrm{K}-10$ mengalami miskonsepsi, setelah dilakukan proses pembelajaran interactive demonstration $\mathrm{K}-10$ dapat menjawab sesuai dengan konsep tekanan hidrostatika dan mengubah miskonsepsi menjadi konsep yang benar. Dalam hal ini terjadi proses Akomodasi.

\section{2) Soal tentang Tekanan Hidrostatika}

Disajikan sebuah gambar permukaan air dengan tinggi dan bentuk wadah yang berbedabeda. Siswa diminta untuk menjelaskan titik manakah yang mengalami tekanan lebih besar dan menjelaskan mengapa hal tersebut dapat terjadi. Hasil perubahan konsep K-11 dapat dilihat pada Tabel 6

Tabel 6 Perbandingan jawaban pretest dan posttest K-11

\begin{tabular}{|c|c|}
\hline No & Jawaban Siswa \\
\hline 2 & \\
\hline Pretest & $\begin{array}{l}\text { 2.) Titik C ! Karena Titk C Bed Berada Paung Baver } \\
\text { Sebelah Kiri. }\end{array}$ \\
\hline Posttest & $\begin{array}{l}\text { Titik C! karena Semakin dolannya dersebut, Sewak } \\
\text { BEser Tekanannya. }\end{array}$ \\
\hline
\end{tabular}


Berdasarkan Tabel 6, dapat dilihat bahwa pada saat pretest K-11 dapat menjawab dengan benar tetapi tidak dapat menjelaskan sesuai dengan konsep tekanan hidrostatika. Setelah dilakukan proses pembelajaran interactive demonstration, $\mathrm{K}-11$ mulai memahami tentang konsep tekanan hidrostatika dan dapat menjelaskan mengapa hal tersebut dapat terjadi. Dalam hal ini terjadi proses asimilasi.

\section{3) Konsep tentang Tekanan Hidrostatika}

Diberikan sebuah kasus contoh penerapan, siswa diminta untuk menjelaskan mengapa bendungan dibuat lebih lebar penampangnya pada bagian bawah dan menjelaskan mengapa hal tersebut dapat terjadi. Hasil perubahan konsep K-05 mengenai konsep hidrostatika dapat dilihat pada Tabel 7.

Tabel 7 Perbandingan jawaban pretest dan posttest K-05

\begin{tabular}{|c|c|}
\hline No & \multicolumn{1}{|c|}{ Jawaban Siswa } \\
\cline { 1 - 1 } Pretest & $\begin{array}{l}\text { Karna bagian bawah tanggul akan } \\
\text { menampung lebih banyak air. }\end{array}$ \\
\hline Posttest & $\begin{array}{l}\text { Karna tanggul menampung kir, jadi kernapa } \\
\text { langu! di bawahnya di buat anak lebih } \\
\text { lebar (Kuat) karna tekanan airnya yang } \\
\text { semakin daiam sumakin besar. }\end{array}$ \\
\hline
\end{tabular}

Berdasarkan Tabel 7, dapat dilihat bahwa pada saat pretest K-05 belum dapat menjawab sesuai dengan konsep tekanan hidrostatika. Setelah dilakukan pembelajaran interactive demonstration $\mathrm{K}-05$ mulai memahami tentang hubungan kedalamam dan ketinggian zat cair terhadap bentuk bendungan. Dalam hal ini terjadi proses asimilasi

\section{4) Konsep tentang Hukum Pascal}

Disajikan sebuah gambar prinsip kerja mesin pengangkat mobil, siswa diminta untuk menjelaskan apa yang terjadi pada mobil saat penampang $\mathrm{F}$ ditekan? Jelaskan! hasil perubahan konsep K-09 dapat dilihat pada Tabel 8.

Tabel 8 Perbandingan jawaban pretest dan posttest K-09

\begin{tabular}{|c|c|}
\hline No & Jawaban Siswa \\
\hline 4 & \\
\hline \multirow[t]{3}{*}{ Pretest } & Benda M tidak Mencalami Perubahan kaven a \\
\hline & benda M terlalu berat, tidak dapat terangkat \\
\hline & dengan Gaya Sebesar \\
\hline \multirow[t]{4}{*}{ Posttest } & Benda M akan terangkat dengan mudah Soat \\
\hline & Penampang 1 ditekan dengan saya sebesar $F$ \\
\hline & $\begin{array}{l}\text { hal ini sesuai dengan hukuin Pascal, gaya yang } \\
\text { bekerja pada sueh zat cair Pada ruang tertutuj }\end{array}$ \\
\hline & akan diteruskan ke segala arah sama besar \\
\hline
\end{tabular}

Berdasarkan Tabel 8, dapat dilihat bahwa pada saat pretest K-09 mengalami miskonsepsi. Setelah dilakukan proses pembelajaran interactive demonstration, K-09 dapat menjawab sesuai dengan konsep hukum pascal dan dapat mengubah miskonsepsi menjadi konsep yang benar. Dalam hal ini K-09 mengalami akomodasi.

\section{5) Konsep tentang Hukum Archimedes}

Diberikan sebuah kasus, siswa diminta untuk menjelaskan mana yang lebih mudah terapung saat di kolam atau di laut dan menjelaskan mengapa hal tersebut dapat terjadi.Hasil perubahan konsep K-04 dapat dilihat pada Tabel 9.

\begin{tabular}{|c|c|}
\hline $\begin{array}{c}\mathrm{No} \\
5\end{array}$ & Jawaban Siswa \\
\hline Pretest & 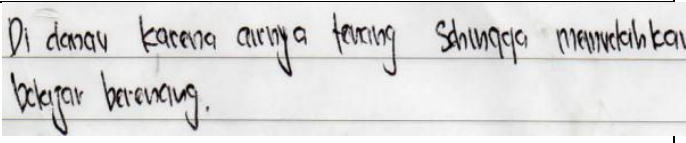 \\
\hline Posttest & 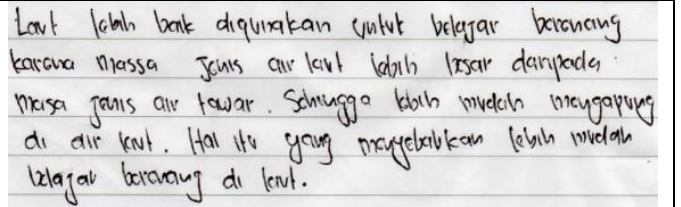 \\
\hline
\end{tabular}

Berdasarkan Tabel 9, dapat dilihat bahwa Pada saat pretest K-04 mengalami miskonsepsi mengenai konsep terapung. Setelah dilakukan proses belajar mengajar dengan menggunakan pembelajaran interactive demonstration, $\mathrm{K}-04$ dapat mengubah miskonsepsi menjadi konsep yang benar. Dalam hal ini terjadi proses akomodasi.

\section{6) Konsep tentang Hukum Archimedes}

Diberikan sebuah kasus tentang telur yang mula-mula tenggelam, setelah pemberian garam menjadi terapung, siswa diminta untuk menjelaskan mengapa hal tersebut dapat terjadi. Hasil perubahan konsep K-17 dapat dilihat pada Tabel 10.

Berdasarkan Tabel 10, dapat dilihat bahwa Pada saat pretest $\mathrm{K}-17$ mengalami miskonsepsi mengenai konsep terapung. Setelah dilakukan proses belajar mengajar dengan menggunakan pembelajaran interactive demonstration, $\mathrm{K}-17$ dapat mengubah miskonsepsi menjadi konsep yang benar. Dalam hal ini terjadi proses akomodasi.

Tabel 10 Perbandingan jawaban pretest dan posttest $\mathrm{K}-17$

\begin{tabular}{|r|r|}
\hline N0 & Jawaban Siswa \\
\hline
\end{tabular}




\begin{tabular}{|c|c|}
\hline 6 & \\
\hline \multirow[t]{4}{*}{ Pretest } & Air yo Jelah dimasukan garart, bisa thertbuat \\
\hline & Sesuatu Hengapung dipertiukaan Air Jersebut \\
\hline & Karena kadar garan bisa Hertbuat thassa \\
\hline & benda terseput thenjadi kecil. \\
\hline \multirow[t]{5}{*}{ Posttest } & Sebeluta diberikan garart thassa - massa Jenis ait \\
\hline & Cebih kecil dari thassa Jenis telur sehingga telur \\
\hline & Tenggelart, setelah dibarikan garant thassa Jenis \\
\hline & Air lebih besar dari Mlassa fenis felur schingga \\
\hline & Telur than \\
\hline
\end{tabular}

7) konsep tentang Hukum Archimedes

Disajikan sebuah peristiwa dalam kehidupan sehari-hari tentang benda yang dapat terapung, melayang dan tenggelam ketika dimasukkan kedalam zat cair kemudian menjelaskan mengapa hal tersebut dapat terjadi. Hasil perubahan konsep K-14 mengenai konsep melayang, terapung dan tenggelam dapat dilihat pada Tabel 11 .

Tabel 11 Perbandingan jawaban pretest dan posttest K-14

\begin{tabular}{|c|c|}
\hline$\frac{\text { No }}{7}$ & Jawaban Siswa \\
\hline Pretest & $\begin{array}{l}\text { Herpaing tarena bendanya ringan } \\
\text { morlayang karena bendanya gerimbang dengan air } \\
\text { Tenggelam kasena bendanyn Berat. }\end{array}$ \\
\hline Posttest & $\begin{array}{l}\text { Terapung karena masa jenis air lebih besar } \\
\text { dari massa jenis benda } \\
\text { melayang karenn massa jenis air samn } \\
\text { dengan masa jenis benda } \\
\text { melayang karena massa jenis air sama } \\
\text { dengan massa jenis benda } \\
\text { trenggejam karena massa jenis air lebih } \\
\text { dari massa jenis benda }\end{array}$ \\
\hline
\end{tabular}

Berdasarkan Tabel 11, dapat dilihat bahwa Pada saat pretest $\mathrm{K}-14$ mengalami miskonsepsi mengenai konsep terapung,melayang dan teggelam. Setelah dilakukan pembelajaran interactive demonstration, $\mathrm{K}-14$ dapat mengubah miskonsepsi menjadi konsep yang benar. Dalam hal ini terjadi proses akomodasi.

\section{8) Soal tentang hukum archimedes}

Diberikan fenomena tentang kapal yang bisa terapung di permukaan air, siswa diminta untuk mendeskripsikan mengapa kapal yang terbuat dari besi bisa terapung di atas air dan menjelaskan mengapa hal tersebut dapat terjadi. Hasil perubahan konsep K-07 mengenai konsep melayang, terapung dan tenggelam dapat dilihat pada Tabel 12.

Berdasarkan Tabel 12, dapat dilihat bahwa Pada saat pretest $\mathrm{K}-07$ mengalami miskonsepsi mengenai konsep terapung, melayang dan tenggelam. Setelah dilakukan pembelajaran interactive demonstration, $\mathrm{K}-17$ dapat mengubah miskonsepsi menjadi konsep yang benar. Dalam hal ini terjadi proses akomodasi

\begin{tabular}{|c|c|}
\hline No & Jawaban Siswa \\
\hline 8 & JdWdDdII SISWd \\
\hline Pretest & $\begin{array}{l}\text { Karena kapal laut memiliki tekanan } \\
\text { udara saat berada di laut. }\end{array}$ \\
\hline Posttest & $\begin{array}{l}\text { Masa Jenis total kapal lebih kecil. } \\
\text { dari massa Jenis air sehingga kapal } \\
\text { laut dapat terapung di permukaan air }\end{array}$ \\
\hline
\end{tabular}

\section{Pembahasan}

Penelitian ini bertujuan untuk mengetahui pengaruh pembelajaran interactive demonstration terhadap perubahan konsep siswa tentang tekanan zat cair pada Kelas VIII SMP Negeri 14 Palu. Dalam penelitian ini digunakan dua sampel yaitu kelas eksperimen dengan pembelajaran interactive demonstration dan kelas kontrol dengan pembelajaran konvensional. Siswa yang menjadi sampel penelitian diberikan tes awal (pretest) dan tes akhir (posttest) untuk melihat terdapat tidaknya pengaruh perubahan konsep siswa. Tes perubahan konsep pada pretest sama dengan pada posttes terdiri dari 8 butir soal esai pemahaman konsep, soal tersebut dirancang untuk menimbulkan konflik kognitif pada fikiran siswa. Sebelum diujikan, soal terlebih dahulu divaliditas melalui expert validator kemudian divaliditas item.

Berdasarkan Tabel 2 dapat diketahui bahwa pada skor rata-rata pretest kelas eksperimen adalah 18.06 sedangkan untuk kelas kontrol adalah 19,17 perbedaan skor rata-rata kedua kelompok hasil pretest kecil, hal tersebut disebabkan kedua kelompok samasama terdistribusi merata pada kedua kelas yang dijadikan sampel penelitian. Pada saat dilakukan posttest diperoleh skor rata-rata seperti pada Tabel 2 yaitu kelas eksperimen sebesar 78.47 dan kelas kontrol sebesar 57,36. $\mathrm{N}$-gain kelas eksperimen sebesar 73,82 dan $\mathrm{N}$ gain kelas kontrol sebesar 46,84. Skor $N$-gain tersebut menunjukkan bahwa kelas eksperimen yang menerima materi dengan pembelajaran interactive demonstration memperoleh peningkatan perubahan konsep lebih tinggi daripada kelas kontrol yang menerima materi dengan pembelajaran konvensional.

Perbandingan persentase peningkatan perubahan konsep siswa pada setiap soal dapat dilihat pada Gambar 3. 


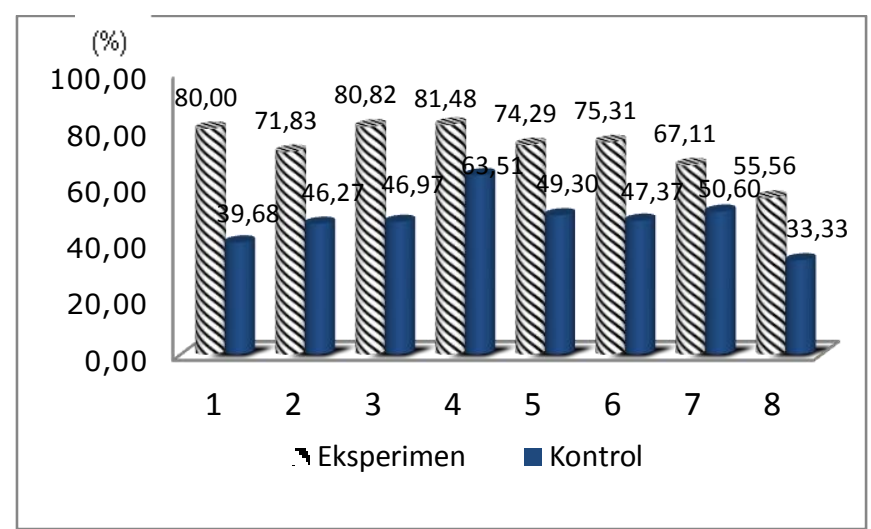

Gambar 3 Grafik perbandingan Skor Rata-rata Pretest dan Posttest pada Kelas Eksperimen dan Kelas Kontrol untuk Setiap soal

Berdasarkan grafik pada Gambar 3, dapat diketahui bahwa peningkatan perubahan konsep kelas eksperimen lebih baik daripada kelas kontrol, menunjukkan adanya pengaruh pembelajaran yang diterapkan pada kedua kelas tersebut. Pengaruh yang signifikan terjadi pada kelas eksperimen.

Berdasarkan uji Mann-Whitney diperoleh hasil untuk $u_{\text {hitung }}$ sebesar 10,5 sedangkan $u_{\text {tabel }}$ 109. Nilai $u_{\text {hitung }} \leq u_{\text {tabel }}$ dengan demikian $H_{\circ}$ ditolak dan $\mathrm{H}_{1}$ diterima, artinya terdapat perbedaan hasil belajar antara kelas yang mendapatkan pembelajaran interactive demonstration dengan kelas yang mendapatkan pembelajaran konvension.

Hasil analisis diketahui bahwa terdapat pengaruh pembelajaran interactive demonstration terhadap perubahan konsep siswa tentang tekanan zat cair pada Kelas VIII SMP Negri 14 Palu. Penelitian ini sejalan dengan penelitian yang mengemukakan bahwa penggunaan model pembelajaran demonstrasi interaktif berbantuan multmedia berpengaruh terhadap hasil belajar siswa SMP pada mata pelajaran IPA aspek kimia ${ }^{[7]}$.

Dari hasil penelitian diketahui bahwa tiap tahap dalam pembelajaran interactive demonstration dapat menghubungkan terjadinnya perubahan konsep pada siswa. Tahap awal yaitu predict, pada tahap ini masing-masing siswa diberi kesempatan untuk memprediksi mengenai permasalahan yang diberikan. Diawali dengan memberikan sebuah pertanyaan berupa fenomena dalam kehidupan sehari-hari untuk menarik minat siswa dalam belajar. Guru membagi siswa menjadi beberapa kelompok kecil dan memberikan sebuah pertanyaan secara beruntun berupa masalahmasalah dalam kehidupan sehari-hari untuk menimbulkan konflik kogntif dalam pikiran siswa. Siswa mengajukan dugaan (hipotesis) terhadap pertanyaan deskriptif dan kausal yang diberikan. Melalui tahap predict dapat diketahui terdapat tidaknya miskonsepsi pada siswa.

Tahap kedua yaitu fase experience, dilakukan kegiatan demonstrasi disertai tanya jawab antara guru dan siswa bersifat interaktif untuk membuktikan hipótesis yang diajukan. Pada tahap ini siswa dapat melihat langsung peristiwa yang terjadi melalui peragaan dengan menggunakan alat bantu untuk memperjelas gambaran siswa tentang materi yang dipelajari sehingga siswa mendapatkan konsep baru yang dapat dimengerti dan masuk akal serta dapat meluruskan miskonsepsi siswa dengan adanya tanya jawab secara interaktif. Melalui fase eksperience siswa dapat mengubah miskonsepsi menjadi konsep yang tepat.

Tahap terakhir yaitu fase reflect, setelah membuktikan hipótesis, siswa mengidentifikasi perbedaan antara hipótesis dan hasil pengamatan serta memberikan alternatif penjelasan terhadap hasil pengamatan mereka. Melalui fase reflect konsep siswa dapat betulbetul berubah menjadi konsep yang tepat sehingga siswa dapat mengubah konsepnya dari konsep yang kurang tepat menjadi konsep yang tepat. Keterlaksanaan pembelajaran ini dapat diamati menggunakan format lembar observasi aktifitas guru dan aktifitas siswa. Lembar observasi yang digunakan disesuaikan dengan tahap-tahap pembelajaran interactive demonstration.

Berdasarkan tabel 4 dapat dilihat bahwa Hasil analisis observasi aktivitas siswa dan guru berkembang lebih baik pada tiap pembelajaran. Dapat dilihat dari rerata persentase akitivitas siswa yang mencapai $86,43 \%$ berada pada kategori baik Sedangkan peran guru dalam memberikan perlakuan ditiap pertemuan mencapai $90,22 \%$ berada pada kategori sangat baik. Kerjasama siswa terjalin dengan baik antara siswa dan guru maupun antar siswa itu sendiri. Peningkatan ini menunjukkan bahwa jika siswa diberikan kesempatan untuk mencari, menemukan dan menyimpulkan maka siswa mempunyai kesempatan untuk mengembangkan pengetahuannya. Partisipasi siswa pun menjadi meningkat karena keingintahuan siswa terhadap kebenaran dari pengetahuan yang dimilikinya.

Kelebihan dari pembelajaran Interactive demonstration dibandingkan konvensional adalah memberi kesempatan kepada siswa untuk berfikir dan menantang siswa ketika prediksi tidak sesuai dengan pengamatan, membuat pembelajaran menjadi lebih menarik sebab siswa tidak hanya mendengar tetapi juga melihat peristiwa yang terjadi melalui peragaan sehingga dapat mengubah miskonsepsi siswa 
dan pada akhirnya dapat bermuara pada perubahan konsep

Berdasarkan analisis data, perubahan konsep yang terjadi pada siswa sangat baik setelah dilakukan pembelajaran interactive demonstration. Namun, walaupun semua siswa mengalami perubahan konsep secara baik masih terdapat miskonsepsi pada setiap konsep yang ada. Hal ini disebabkan siswa memiliki konsep awal dan ini sangat bersifat resisten. Hasil ini sesuai dengan pernyataan [3] yang menyatakan bahwa Konsep yang bertentangan dengan teori atau konsep awal siswa tidak selalu diterima. Siswa yang tidak menerima, tidak akan menghasilkan perubahan konsep secara kuat sedangkan bila menerima akan menghasilkan perubahan konsep secara kuat yaitu akomodasi'

\section{KESIMPULAN}

Berdasarkan hasil dan analisis data penelitian maka dapat disimpulkan bahwa terdapat pengaruh pembelajaran interactive demonstration terhadap perubahan konsep siswa tentang tekanan zat cair pada Kelas VIII SMP Negeri 14 Palu

\section{DAFTAR PUSTAKA}

[1] Suparno, P. (1997). Filsafat Konstruktivisme dalam Pendidikan. Yogyakarta: Kanisius

[2] Suparno, p. (2013). Miskonsepsi dan Perubahan Konsep dalam Pendidikan Fisika. Jakarta: PT Grasindo.

[3] Sadia, I W., Suastra, I. W., \& Tika, K. (2004). Pengembangan model dan strategi pembelajaran fisika di sekolah menengah umum (SMU) untuk memperbaiki miskonsepsi siswa. Laporan Penelitian. Institut Keguruan dan Ilmu Pendidikan Negeri Singaraja.

[4] Posner, G., Strike, K., Hewson, P., \& Getzog, W. (1982). "Accommodation of a scientific conception: Toward a theory of conceptual change". Science Education, 66, (2), 221-227.

[5] Muyassaroh, I Z. (2015). Pengaruh Level Of InquiryInteractive Demonstration Terhadap Kemampuan Pemecahan Masalah Fisika Peserta Didik Kelas $X$ Sma. Skripsi. Universitas Negri Malang.

[6] Kwon, J. (2006) The Effects of Cognitive Conflict On Students Conceptual Change in Physics. Jounal of physics Education korean national university. 4, (1), 64-79.

[7] Wijaya, W B. (2012). "Model demonstrasi interaktif berbantuan Multimedia dan hasil belajar ipa Aspek kimia siswa smp" jurnal pendidikan dan pengajaran. 45, (1), 88-98. 